Annales Missiologici Posnanienses t. 25 (2020), s. 7-21

doi: $10.14746 / \mathrm{amp} .2020 .25 .1$

ORCID: 0000-0001-6543-1440

\author{
DOROTA KOŁODZIEJCZYK \\ Uniwersytet Kardynała Stefana Wyszyńskiego w Warszawie \\ Wydział Nauk Historycznych
}

\title{
Chrystianizacja Anglii według Historia ecclesiastica gentis Angelorum Bedy Czcigodnego
}

Historia ecclesiastica gentis Angelorum św. Bedy Czcigodnego, będąca powstałą we wczesnym średniowieczu kroniką, obejmuje okres: od przybycia Juliusza Cezara na Wyspę do $731 \mathrm{r}$. Jest ona jednym z niewielu zachowanych do dzisiaj źródeł dokumentujących dzieje heptarchii. W niniejszym artykule zaprezentowane zostaną, na bazie dostarczonych przez tę kronikę informacji, początki chrystianizacji Wyspy ${ }^{1}$.

\section{Kilka słów o kronikarzu}

Beda Czcigodny (łac. Venerabilis) ${ }^{2}$ uchodził za najbardziej uczonego w gronie świętych i za najbardziej świętego w gronie uczonych Kościoła (por. Puchalska-Dąbrowska, Postać Bedy Czcigodnego w polskim piśmiennictwie religijnym XVI-XVIII wieku 19). Uosabiał ponadto, i to znakomicie, ,syntezę celtyckich, anglosaskich i rzymskich tradycji” (Leciejewicz 208), dając temu wyraz w swoim piśmiennictwie. Urodził się w 673 lub 678 r. w Wearmouth, w pobliżu Durham, lub w Jarrow (Northumbria) (por. Karas 9; Puchalska-Dą-

\footnotetext{
${ }^{1}$ Wydawnictwo Naukowe UKSW w Warszawie wydało w 2020 r. przetłumaczoną z języka łacińskiego kronikę Bedy Czcigodnego (seria: Pisma starochrześcijańskich pisarzy, t. LXXIV): Beda Czcigodny, Dzieje Kościoła Anglów, w przekładzie Iwonny Salamonowicz-Górskiej.

${ }^{2}$ Przydomek „Czcigodny” nadano Bedzie na synodzie w Akwizgranie w 836 r. ze względu na zasługi i autorytet tego benedyktyna. Porównywany ze świętymi: Augustynem, Hieronimem, Ambrożym i Izydorem, darzony czcią od IX stulecia, wyniesiony został w 1899 r. na ołtarze i ogłoszony Doktorem Kościoła przez papieża Leona XIII (Puchalska-Dąbrowska, Beda Czcigodny i bohaterowie „Historii kościelnej narodu angielskiego” w polskim piśmiennictwie religijnym XVI-XVIII wieku 331; por. Karas 10; por. Delap 14).
} 
browska, Postać Bedy Czcigodnego w polskim piśmiennictwie religijnym XVI-XVIII wieku 331; Marecki i Rotter 105). Jako siedmiolatek, oddany został na wychowanie do benedyktyńskiego klasztoru pw. św. Piotra w Wearmouth, gdzie pieczę nad nim sprawował Benedykt Biscop, opat w Wearmouth i Jarrow oraz założyciel opactwa w Wearmouth. Po trzech latach pobytu w tym opactwie udał się do Jarrow, w którym spędził pozostałą część życia. Tam też zaznajomił się z kulturą grecką, a uczył go np. Jan z Beverley, biskup Yorku. Do grona nauczycieli i uczniów, z którymi Beda Czcigodny zaprzyjaźnił się, należeli m.in.: Vertbert, Kutbert, Nothelm, Albinus i Akkon. Niezwykle płodny piśmienniczo Beda Czcigodny posługiwał się ponadto biegle językami: hebrajskim, greckim i łacińskim. Ów benedyktyn zmarł w opinii świętości w dniu 25 (lub 26) marca 735 r. w Jarrow, nie ukończywszy ostatniego swego wielkiego dzieła: przekładu Ewangelii według św. Jana i fragmentów pism św. Izydora z Sewilli, czego podjął się pod protektoratem Egberta, biskupa Yorku (więcej o jego życiu i piśmiennictwie: por. Sprutta i Kołodziejczyk 191-203).

\section{Kronika Bedy Czcigodnego}

Do Historiae ecclesiasticae gentis Anglorum, stanowiącej nie tylko zapis starożytnych (od epoki Juliusza Cezara), ale i wczesnośredniowiecznych dziejów Anglii, Beda Czcigodny dołączył notkę autobiograficzną z wykazem dzieł. To właśnie dzięki owej kronice, będącej jednym z najwybitniejszych osiągnięć wczesnośredniowiecznej historiografii zachodnioeuropejskiej, składającym się z pięciu ksiąg, jej autor zyskał wielkie uznanie. Przyczyniła się ona do nazwania go „ojcem historiografii angielskiej” (por. Karas 10; por. Puchalska-Dąbrowska, Postać Bedy Czcigodnego w polskim piśmiennictwie religijnym XVI-XVIII wieku 331).

Następująco o tej kronice, powstałej około 731 r., pisze sir Frank Stenton:

To konstytutywna jakość Historii Bedy umieszcza ją w wąskiej grupie książek, które przewyższają inne o podstawowych warunkach czasu i miejsca..., ta jakość czyni to dzieło wielkim nie ze względu na jego wiedzę czy narrację, które Beda dzielił z wieloma mu współczesnymi, lecz jego zdumiewającą umiejętność koordynowania fragmentów informacji pozyskanych przez niego z tradycji, przekazu przyjaciół lub poświadczone przez dokumenty. W czasach, kiedy niewiele ponad zapisami faktów było dostępne, on dotarł do koncepcji historii (Stenton 187).

Natomiast sam autor w taki oto sposób wypowiada się w kwestii tworzenia kroniki: 
A więc od okresu, w którym ten tom zaczyna się, aż do czasu, gdy naród angielski otrzymał wiarę w Chrystusa, zająłem się kompleksowo pracami wcześniejszych pisarzy, zgromadzonymi w rozmaitych źródłach. Lecz od tamtego czasu do chwili obecnej posiadam o wiele więcej informacji o tym, czego dokonał Kościół w Canterbury dzięki uczniom papieża Grzegorza i ich następcom, i za panowania których królów miały miejsce wydarzenia, pilność wspomnianego opata Albinusa pozwoliła mi poznać Nothelma (Bede 42).

Pisząc kronikę, Beda Czcigodny posłużył się metodą opisu, inspirowaną poetyką ksiąg historycznych Starego Testamentu ${ }^{3}$ oraz Historia kościelna Euzebiusza z Cezarei (w opracowaniu Rufina z Akwilei). Wiadomości o najdawniejszych dziejach chrześcijaństwa w Brytanii zaczerpnął od Orozjusza, Prospera z Akwitanii, Gildasa Mądrego i Albina, opata z Canterbury. Bazował także m.in. na dostarczanych mu $\mathrm{z}$ klasztorów i innych instytucji religijnych z całej Brytanii np. zapiskach z obrad synodów, opowieściach hagiograficznych, germańskich i chrześcijańskich konwencjach narracyjnych i na tradycji ustnej, co tłumaczy łączną obecność w kronice i cudownych zdarzeń, i faktów uwzględnionych w źródłach. W kronice charakteryzującej się rzeczowością, językiem bazującym na późnoantycznych wzorcach i zastosowaniem liczenia lat na podstawie ery Chrystusowej przybliżył m.in. proces unifikacji i konsolidacji chrześcijaństwa, stanowiący konsekwencję działalności misjonarzy: Patryka, Kolumbana (Starszego), Augustyna z Canterbury, Niniana, Aidana i Dawida. Ukazał też konflikt między Kościołami rzymskim i iroszkockim w kwestii chociażby daty Wielkanocy i celebracji sakramentalnej. Opisał działalność misyjną ludzi Kościoła na Wyspie, o której to działalności artykuł traktuje poniżej. Nie omieszkał wspomnieć również - jako pierwszy - o Caedmonie, znanym $\mathrm{z}$ imienia pierwszym angielskim poecie, autorze m.in. hymnu ku czci Boga Stwórcy, utworu stanowiącego najdawniejszy zabytek poezji religijnej w języku anglosaskim (por. Puchalska-Dąbrowska Postać Bedy Czcigodnego w polskim piśmiennictwie religijnym XVI-XVIII wieku; por. Bober 95).

Intrygująca jest też przedmowa Bedy Czcigodnego do kroniki. Następująco zwraca się w niej do Ceolwulfa, króla Northumbrii, któremu dzieło to w 731 r. zadedykował:

Jakiś czas temu, na prośbę Waszej Wysokości, z radością posłałem Wam historię Kościoła i ludu angielskiego, którą właśnie ukończyłem, abyś mógł, Wasza Wysokość, przeczytać i wyrazić swoją aprobatę. Teraz posyłam ponownie do przepisania, aby Wasza Wysokość mógł przeczytać z większą przyjemnością. Z zadowoleniem przyjąłem gorący zapał, z jakim Wasza Wysokość studiujesz Biblię

${ }^{3}$ W efekcie tego kroku zaprezentował Beda Czcigodny, np. anglosaskich królów, bazując na sposobie kreowania bohaterów w Piśmie Świętym, a ich historie miały stanowić moralny przykład. 
i Wasze gorące pragnienie uzyskania wiedzy o poczynaniach i przekazie ludzi z przeszłości, zwłaszcza o sławnych ludziach z twojego narodu. Dlatego historia zapisuje dobre rzeczy o dobrych ludziach, uważny słuchacz jest zachęcany do naśladowania tego, co dobre albo, jeśli zapisuje zło nikczemnych ludzi, wtedy oddany religii słuchacz lub czytelnik zachęcany jest do omijania wszystkiego, co grzeszne i strzeżenia się, aby podążał za tym, o czym wie, że jest dobre i miłe Bogu (Bede 41).

Na końcu tego historiograficznego dzieła jego autor umieścił również modlitwę, która, stanowiąc też świadectwo pokory świętego dziejopisa, brzmi następująco:

O dobry Jezu,

Jak dozwoliłeś mi czerpać

Słodycz słów Twojej mądrości,

Tak dozwól mi, proszę

Dojść kiedyś do Ciebie -

Źródła wszelkiej wiedzy,

I przed Twoim

Trwać zawsze obliczem.

Amen (cyt. za Bober 95).

\section{Początki Kościoła na Wyspie}

O chrześcijaństwie w Brytanii najwcześniej wzmiankowali Tertulian i Orygenes, choć wątpliwe jest, aby mieli oni kontakt z najbardziej odległymi prowincjami Cesarstwa Rzymskiego. Przypuszcza się, że na początku III w. chrześcijaństwo istniało już na Wyspie (miało pojawić się na niej w II w.). Nadto akta synodu zwołanego w 314 r. w Arles (Galia) wymieniają pięciu obecnych na nim duchownych z Brytanii, mianowicie: trzech biskupów reprezentujących Londyn, Lincoln i York, a także prezbitera i diakona przybyłych prawdopodobnie z Cirencester (Snyder 117). Przedstawiciele chrześcijan-Brytów mieli też uczestniczyć w tej epoce w synodach w Rzymie. Niemniej jednak dopiero w VI stuleciu Brytania przyjęła chrzest, do czego przyczynił się irlandzki misjonarz z klasztoru na wyspie Iona (Hy) (u wybrzeży Szkocji) Kolumban Starszy.

Pierwszym natomiast najbardziej znanym męczennikiem Brytanii był św. Alban. Został umęczony wraz ze swoimi towarzyszami w okolicach rzymskiego Verulamium (obecnie: St. Albans, nazwa od imienia męczennika) za panowania Dioklecjana. Data męczeńskiej śmierci św. Albana nie jest pewna: podaje się, że zginął, ścięty, około $304 \mathrm{r}$. lub w połowie III w., albo na roz- 
kaz Gety w 209 r. Beda Czcigodny znał Pasje św. Albana, prawdopodobnie z wersji datowanej na lata 500-550. Święty Alban był rzymskim żołnierzem, zamożnym mieszkańcem Verulamium. Jeszcze jako poganin, udzielił schronienia chrześcijańskiemu kapłanowi uciekającemu przed prześladowaniem. Do nawrócenia Albana przyczyniła się niezłomna wiara i gorliwość owego kapłana. Pod wpływem łaski Bożej stał się on równie gorliwym i zdolnym do poświęceń chrześcijaninem. Gdy wieść o ukrywającym się kapłanie ujrzała światło dzienne, przeszukano dom Albana, który chroniąc kapłana, przebrał się w jego szaty i po pojmaniu znalazł się przed obliczem sądu. Kiedy sędzia zakazał Albanowi występowania przeciwko bogom, ten odmówił przestrzegania owego zakazu. Beda Czcigodny nie omieszkał też wspomnieć o męczeństwie (za panowania Decjusza i Waleriana) pochodzących, prawdopodobnie z Caerleon-on-Usk, m.in. Aarona i Juliusza (por. Bede 53-54). Znane są także imiona jeszcze innych brytyjskich męczenników z tego okresu, mianowicie: łączonego z Londynem biskupa Augulusa i żołnierza Mellonusa (Snyder 117-118). Warto też dodać, że u zarania chrześcijaństwa na Wyspie legendarny król Brytów Lucjusz miał, co uwzględnił w swej kronice jako fakt Beda Czcigodny, napisać do papieża Eleuteriusza list, prosząc w nim, i to skutecznie, o uczynienie siebie chrześcijaninem (Bede 49). W efekcie owego kroku Brytowie stali się chrześcijanami zachowującymi niezmienioną wiarę do momentu wszczęcia przez Dioklecjana prześladowań wyznawców Jezusa Chrystusa, które to prześladowania trwały w Brytanii przez dekadę (Bede 51). Po prześladowaniach, ukrywający się dotychczas przed nimi, np. w grotach, Brytowie zaczęli odbudowywać lub ponownie wznosić miejsca chrześcijańskiego kultu, poświęcając je także męczennikom.

Abstrahując od prześladowań stanowiących wielką próbę dla wczesnego chrześcijaństwa, Beda Czcigodny wspomniał również o docierających do Brytów herezjach, jakimi były: arianizm, potępiony w 325 r. na soborze w Nicei, i pelagianizm, potępiony na synodach w Kartaginie (418 r.) i Orange (529 r.) oraz na soborze w Efezie (431 r.) (Pelagiusz był Brytem) (por. Snyder 125). Przeciwko błędnej doktrynie pelagiańskiej wystąpił w Brytanii przybyły z Galii jako legat papieski m.in. w tym celu na Wyspę - z wykształcenia prawnik - biskup German z Auxerre, którego dokonania benedyktyn-dziejopis skrupulatnie opisał w swej kronice. Germanowi towarzyszył w pierwszej wyprawie do Brytanii biskup Lupus z Troyes. To właśnie o Germanie Beda Czcigodny napisał, że „,Z Bożą pomocą stłumił dwie burze, jedną na morzu, drugą pelagiańską" (Bede 65,67; por. Snyder 217). Do owej „,burzy pelagiańskiej” przyczynił się Agrykola, syn pelagiańskiego biskupa Seweriana. German podjął się uczestniczenia w ,subtelnym” sporze ze zwolennikami pelagianizmu w Brytanii, ponieważ Brytowie, mimo iż bronili się przed błędną doktryną, nie byli w stanie zmierzyć się z nimi na argumenty wobec herezji zwanej przez Bedę 
Czcigodnego „bluźnierstwem przeciwko łasce Bożej” (Bede 65). Podróży morskiej obu biskupów nadał Beda Czcigodny charakter poniekąd cudowny, pisząc:

Pierwszą połowę drogi z Galii do Brytanii przebyli z pomyślnym wiatrem, gdy nagle zostali poddani niespodziewanemu napadowi nieprzyjacielskiej siły demonów, które były wściekłe, że tacy ludzie ośmielają się zawrócić Brytów na drogę zbawienia. Wznieciły sztorm i zasnuły niebo ciemnymi chmurami, tak, że zrobiła się noc. Żagle nie mogły wytrzymać porywów wiatru, na nic zdały się umiejętności żeglarzy, a losy statku bardziej były zdane na siłę modlitwy niż na owe umiejętności. [...] w momencie, gdy statek już miał zatonąć [...] błogosławiony Lupus [...], wzywając imię Chrystusa i Trójcę Przenajświętszą, wziąwszy odrobinę wody, poświęcił i uciszył ryczące fale, napomniał towarzyszy, by wznieśli głos we wspólnej modlitwie. Bóg pomógł [...] dotarli bezpiecznie do portu (Bede 67).

Obaj biskupi nie tylko mieli skutecznie egzorcyzmować morze, ale i ludzi. Ponadto nie tylko, zdaniem Bedy Czcigodnego, nauczali, ale i czynili cuda, np. German przywrócił za pomocą relikwii apostołów wzrok dziesięcioletniej, niewidomej córce trybuna: jej oczy „natychmiast zostały oswobodzone z ciemności i wypełnione światłem prawdy" (Bede 67,68). Dalej o działalności Germana i Lupusa Beda Czcigodny napisał: „słowo Boże było codziennie przez nich głoszone nie tylko w kościołach, ale nawet na ulicach i polach [...], a ci, którzy stali się wcześniej zdemoralizowani, przyjęli drogę nawrócenia" (Bede 67). Kiedy natomiast w 429 r. German otworzył grób męczennika Albana i złożył w tym grobie, po modlitwie, relikwie apostołów, zabrawszy garść ziemi z miejsca oddania przez owego świętego życia dla Jezusa Chrystusa, gest ten miał przyczynić się do licznych nawróceń (Bede 68). Nadto obaj biskupi udzielali chrztu Brytom, a Bóg opiekował się nimi również na polu bitewnym, gdy wyruszyli do walki z Sasami i Piktami. Następująco tę opiekę ukazał w swej kronice Beda Czcigodny:

Biskupi uzyskali Bożą pomoc dla Brytów. W międzyczasie Sasi i Piktowie, połączywszy siły, utworzyli armię, przyglądając się osłabionym i, jak sądzili, łatwym do pokonania wojskom Brytów. Zwiadowcy zaobserwowali, że [Brytowie - D.K.] przyjmowali chrzest, przeżywali Wielki Post, Wielkanoc, przy ołtarzu wzniesionym ze splecionych konarów. Umocnieni w wierze, dopiero co ochrzczeni, wcześniej wątpiący w ludzkie siły, teraz wszyscy wierzący w siłę Boga, szli naprzód. Przez apostolskich przywódców sam Chrystus rozkazywał w tym obozie. Przed decydującą walką German osobiście dowodził wojskiem. Zebrał najdzielniejszych żołnierzy, zbadał okolicę. Dostrzegł dolinę wśród wzgórz z tej strony, z której spodziewał się ataku. Ustawił tutaj swoje siły i w momencie, gdy wróg zbliżał się, pewien, że Brytowie nieświadomi są jego nadejścia, on [i Lupus - D.K.] [...] 
wraz z całym wojskiem trzykrotnie krzyknęli „Alleluja!”. Echo rozniosło głosy po okolicznych wzgórzach, nieprzyjacielskie wojsko wpadło w panikę, sądząc, że spadają na nie skały i całe niebo. Uciekało w popłochu, walcząc na oślep, wielu $\mathrm{w}$ tej pochopnej ucieczce utonęło w rzece, którą próbowali się przeprawić. Niewinna armia Brytów pokonała wroga [...], nie biorąc udziału [w walce - D.K.]. Zebrano [...] chrześcijańskie siły połączone triumfem niebios. Biskupi pokonali wroga bez przelewu krwi, tego widzialnego i niewidzialnego, powrócili do domów, a szczęśliwy powrót zapewniły im ich własne cuda i cuda świętego Albana (Bede 69,70).

W Brytanii German pojawił się dwukrotnie, drugi raz w 438 r., również w celu zwalczenia (odradzającej się) pelagiańskiej herezji. Poprosiło go o to duchowieństwo Brytanii, dokąd udał się tym razem wraz z biskupem Severusem z Trewiru (uczniem Lupusa), „człowiekiem prostej świętości”, który głosił Ewangelię plemionom Górnej Germanii. Obaj biskupi po przybyciu na Wyspę udzielali błogosławieństwa Brytom, nauczali ich zasad wiary chrześcijańskiej, a także poszukiwali tych, którzy przyłożyli się do odrodzenia pelagianizmu w Brytanii i upominali tych, którzy ulegli owej błędnej doktrynie. Nadto do umocnienia się właściwej wiary „w sercach wszystkich” Brytów miało przyczynić się „publiczne” uzdrowienie syna niejakiego Elafiusa będącego lokalną osobistością (Bede 70). Według Bedy Czcigodnego to dzięki Germanowi Kościół Brytów zwrócił się ku poprawnie rozumianej doktrynie chrześcijańskiej, czyli został przez Germana odbudowany. Po owej misji German udał się do Rawenny, gdzie zmarł (Bede 70).

W V stuleciu zmieniła się diametralnie sytuacja polityczna w Brytanii. Około 430 r. (podaje się też rok 449) przybyli do niej w celach obronnych, na zaproszenie króla Vortigerna, ludy germańskie: Anglowie, Jutowie i Sasi, co zaowocowało w gruncie rzeczy zanikiem chrześcijaństwa na Wyspie. Część celtyckiej ludności zbiegła wówczas do Armoryki i utworzyła państwo zwane potem Bretanią, a część osiadła w Walii i Kornwalii. Niestety owi „goście", zamierzający wpierw podbić północny obszar Wyspy, sprzymierzyli się wkrótce z Piktami i zagrozili Brytom. Niedługo potem spełnili swoją groźbę: pustoszyli kraj, zabijali jego mieszkańców, po czym skazali ich swoją postawą na codzienność w atmosferze terroru. Tragiczną sytuację, w jakiej znaleźli się Brytowie, Beda Czcigodny zinterpretował jako karę Bożą za ich zbrodnie. Do owej kary przyczyniło się m.in. moralne rozprzężenie u Brytów, dostrzegalne w kręgach duchowieństwa i laikatu po odparciu przez nich „barbarzyńców”, czyli „łysych, irlandzkich rabusi” i Piktów (Bede 61). Na to rozprzężenie złożyły się: okrucieństwo oraz powiązana $\mathrm{z}$ umiłowaniem zakłamania nienawiść do prawdy. Beda Czcigodny stwierdził: „nie tylko świeccy byli temu winni, ale nawet Boża owczarnia i jej pasterze, którzy odrzucając lekkie jarzmo Chry- 
stusa, poddali się ciemności, wrogości, kłótniom, walkom, zazdrości i innym podobnym grzechom" (Bede 62). W latach około 440-590 Brytanią zaczęła targać wojna domowa i pogrążanie się Brytów w jeszcze bardziej bulwersujących niż dotychczas zbrodniach (Bede 72). Cieniem na wizerunku Brytów kładła się też ich opieszałość w kwestii chrystianizacji sąsiadujących z nimi ludów. W VI w. celtycki mnich Gildas w kronice $O$ upadku i podboju Brytanii, na której Beda Czcigodny bazował (por. Zins 23), zarzucał Brytom, że mimo iż poznali i przyjęli chrześcijaństwo, nigdy nie nauczali Anglów i Sasów wiary chrześcijańskiej. Także według postępującego za Gildasem Bedy Czcigodnego problemy, jakie Brytom sprawiali Sasi, były aktem sprawiedliwości, czyli „karą boską za to, że nie nawrócili swoich pogańskich sąsiadów”, czyli de facto nie podjęli współpracy z przybyłym do Brytanii w VI w. Augustynem, benedyktyńskim misjonarzem zajmującym się nawracaniem Anglów, o którym to misjonarzu będzie mowa w dalszej części refleksji, (Snyder 146). Dopiero po czterdziestu czterech latach od momentu przybycia ludów germańskich do Brytanii Anglowie zostali zwyciężeni przez Brytów w bitwie pod Badon Hill, którymi dowodził Ambrozjusz Aurelian (Bede 64). Należy dopowiedzieć, że podbój Brytanii przez wspomniane germańskie nacje miał w przyszłości wpłynąć decydująco na formowanie się narodu i państwa angielskiego (określenie od miana: Anglowie), jego języka, instytucji i kultury. Chrześcijaństwo na Wyspie nie przestało rozprzestrzeniać się również po 604 r., w którym to roku zmarł wspierający misje w Brytanii papież Grzegorz I Wielki.

Beda Czcigodny nie pominął też w swej kronice kwestii chrystianizacji Northumbrii, z której przecież się wywodził. Pierwsze kroki mające na celu wprowadzenie chrześcijaństwa w Northumbrii zakończyły się niepowodzeniem po zwycięstwie pogańskiej Mercji, zamieszkiwanej przez Anglów (Zins 23). W bitwie z Mercją zginął Edwin, król Northumbrii, założyciel Edynburga (stolicy Szkocji) oraz rzecznik schrystianizowania Anglii północnej w obrządku rzymskim (Zins 26; por. Puchalska-Dąbrowska, Beda Czcigodny i bohaterowie „Historii kościelnej narodu angielskiego” w polskim piśmiennictwie religijnym XVI-XVIII wieku 67). Chrześcijaństwo w Northumbrii ewoluowało także za panowania Oswalda, następcy Edwina. Król Oswald miał również podarować biskupowi Aidanowi, mnichowi z iroszkockiego klasztoru z Iona, w 634 r. wyspę Lindisfarne jako siedzibę biskupią. Aidan zajął się m.in. nawracaniem Anglosasów (Bede 144; por. Puchalska-Dąbrowska, Beda Czcigodny i bohaterowie „Historii kościelnej narodu angielskiego” $w$ polskim piśmiennictwie religijnym XVI-XVIII wieku 67-68), choć i wtedy powracano do pogaństwa. Beda Czcigodny wspomina np. o Osricu i Eanfridzie, synach Etelfrida, którzy, mimo iż ochrzczeni, po powrocie z wygnania (przebywali wśród Szkotów i Piktów) do kraju i odzyskaniu panowania porzucili wiarę chrześcijańską, zwracając się ku pogaństwu. Zamordowani zostali następnie 
przez „bezbożnego króla Brytów” Cadwallona z Gwynedd, który przejął po nich rządy.

W gronie wielkich ludzi Kościoła Brytanii Beda Czcigodny wymienił również Teodora, biskupa Canterbury. Ten pochodzący z Tarsu i wykształcony w Atenach dostojnik był pierwszym biskupem obejmującym swoją władzą cały Kościół w Anglii. Nadto zwołał synody w Twynford, Hatfield i Hertford, zreorganizował anglosaską prowincję Kościoła, rozgraniczył diecezje i wdrożył zachodnią dyscyplinę kościelną. Więcej, włączył on Kościół anglosaski w orbitę kultury europejskiej, jednocześnie szanując niektóre iroszkockie zwyczaje obecne w życiu monastycznym. Był on, zdaniem Bedy Czcigodnego, ,pierwszym, któremu posłuszny był cały Kościół angielski” (Bede 87; Puchalska-Dąbrowska, Beda Czcigodny i bohaterowie „Historii kościelnej narodu angielskiego" $w$ polskim piśmiennictwie religijnym XVI-XVIII wieku 117-118).

\section{Pierwsi misjonarze Brytanii}

Pracą misyjną zajmowali się we wczesnośredniowiecznej Brytanii mnisi jako misjonarze będący „dzięki łasce Bożej” „zwiastunami prawdy”, mającymi doprowadzić Brytów do właściwej wiary (Bede 72). Pierwszym w gronie najważniejszych ze względu na dokonania był irlandzki benedyktyn, wspomniany już powyżej Kolumban Starszy, opat klasztoru z Iona. Jego misję uznaje się za początkowy etap chrystianizacji Brytanii, a założony przez niego klasztor na wyspie Iona za odgrywający ważną rolę w chrystianizacji Szkocji i północnej Anglii (Zins 24). Około 563 r. znalazł się w Kaledonii, gdzie rozpoczął misję chrystianizacyjną, organizując Kościół na wzór irlandzki i czyniąc się jego zwierzchnikiem. Z wyspy Iona Kolumban rozszerzył swoją działalność misyjną na obszar Szkocji. Wskazuje się, że w 565 r. udał się z Irlandii do Brytanii z zamiarem ewangelizowania Piktów zamieszkujących najbardziej oddalone na północ ziemie Brytanii, gdyż Piktowie z południa nawrócili się już w trakcie misyjnej posługi biskupa Niniana (Cyrek 14). Ninian pracował w Brytanii jako misjonarz na przełomie IV i V stulecia, rozwijając swoją misyjną działalność zwłaszcza wśród Piktów i w jej ramach zakładając w Szkocji (co uczynił również w Irlandii) klasztory. Ninian przyczynił się też do ewolucji kultury celtyckiego obszaru Brytanii, a zorganizowany przez niego Kościół zdobył względy w lokalnych tradycjach klanowych oraz wykształcił liczne cechy, które później Kościół rzymski, udzielający poparcia zjednoczeniowym tendencjom anglosaskich władców, z trudem przełamywał. W V w. misjonarzem na Wyspie był także Palladiusz. Wysłany przez papieża Celestyna I w $423 \mathrm{r}$. do iroszkockich chrześcijan, został ich pierwszym biskupem. Warto też w tym 
miejscu dopowiedzieć, że duchowy fundament misyjnej działalności mnichów irlandzkich stanowiła tzw. idea pielgrzymowania dla miłości Jezusa Chrystusa, ciesząca się w ich gronie największą popularnością (Cyrek 20).

Do rozwoju owocnej posługi przyczynił się wielce swoimi decyzjami papież Grzegorz I Wielki. To on wysłał w 596 lub 597 r. do Anglii grupę misjonarzy-benedyktynów, na czele z Augustynem (zwanym potem Augustynem z Canterbury), prawdopodobnie przeorem benedyktyńskiego opactwa pw. św. Andrzeja na Monte Celio. Zamierzał również utworzyć na Wyspie łącznie dwie metropolie oraz dwanaście biskupstw, lecz nie zdołał w pełni zrealizować tego planu (Zins 24). Postać Augustyna jawi się tutaj jako bardzo ważna, ponieważ to on zapoczątkował ,apostolską działalność” w regionie zamieszkałym przez Anglów (Cyrek 15). Misja budziła obawy u wspomnianych benedyktynów, którzy mieli nauczać angielski lud, dlatego Grzegorz I Wielki zachęcił ich w liście do wytrwania w misyjnej posłudze, jakiej się podjęli i obawiali (Bede 72). Obawy pojawiły się u benedyktyńskich misjonarzy w momencie, gdy natknęli się na ,straszny, przerażający naród pogan, którego języka nie znali" (Bede 73), stąd też zrozumiałe jest, że pod wpływem obaw rozważali powrót do domu i to bezpieczniejszą drogą. Jednak papieskie polecenie obligowało ich do kontynuacji posługi misyjnej. Wyznaczyli wówczas Augustyna, by ten, dotarłszy do Rzymu, uprosił u papieża niezmuszanie ich do zagrażającej im, uciążliwej i niepewnej wyprawy. W odpowiedzi Grzegorz I Wielki napomniał mnichów, zachęcając ich do podążania w misyjnej posłudze przed siebie za słowem Bożym i do zawierzenia się Bogu. Następująco natomiast zwrócił się do Augustyna: „,nie pozwól, aby trud twojej podróży ani głosy ludzi, przez których przemawia szatan, zniechęciły Cię" (Bede 73).

Posługę misyjną Augustyn rozpoczął w 597 r. od nauczania króla Kentu Etelberta na wyspie Thanet, do którego to króla Grzegorz I Wielki wysłał listy i dary (por. Bede 94). Uzyskawszy pozwolenie owego władcy, mógł kontynuować swoją misjonarską działalność w całym Kencie. Ustanowił pierwszą stolicę biskupią w Brytanii, mianowicie w Canterbury, oraz przystąpił do wznoszenia kościoła i opactwa pw. św. św. Piotra i Pawła (por. Bede 74-76). Wspomniany papież miał zapewnić, przez pośrednictwo duchowieństwa (np. Eteriusza, biskupa z Arles), pomoc Augustynowi (por. Bede 89). W liście z 596 r. nakazał Eteriuszowi umożliwienie odpoczynku temu benedyktyńskiemu misjonarzowi podczas jego podróży do Brytanii. Nadto uczynił on Augustyna biskupem, przesyłając mu m.in. paliusz (Bede 90). W kwestii sukcesów na polu misyjnym należy dopowiedzieć też, że Augustyn miał w święto Bożego Narodzenia ochrzcić około 10 tysięcy Brytów, o czym informował w liście z 598 r. Grzegorz I Wielki. Augustyn troszczył się także np. o pokojowe relacje w Kościele. Za zgodą króla Etelberta nawoływał około 603 r. w Augustine's Oak biskupów do braterskich z nim relacji w katolickiej jedności 
i do włączenia się w ewangelizację pogan: biskupi osłabiali powątpiewaniami autorytet Augustyna oraz trwali w sporach związanych z datą Wielkanocy, celebracją sakramentu chrztu i nauczaniem Anglów. Mimo podjętych starań Augustyn nie zdołał osiągnąć porozumienia $\mathrm{z}$ reprezentantami chrześcijańskiej orientacji celtyckiej, opowiadającymi się m.in. za różniącymi się od rzymskich ustaleniami w kwestii daty Wielkanocy (Puchalska-Dąbrowska, Beda Czcigodny i bohaterowie „Historii kościelnej narodu angielskiego” w polskim piśmiennictwie religijnym XVI-XVIII wieku 83). Ciosem dla Kościoła w tym czasie stała się również przepowiedziana przez Augustyna wojna: po zebraniu znacznych sił pod Legacestir król Etelbert nie dość, że pokonał „niewiernych Brytów", to rozgromił mnichów z klasztoru w Bangor (Bede 104). Beda Czcigodny dopowiada też, że wraz z misją chrystianizacyjną w 597 r. przybył razem z Augustynem do Anglii Wawrzyniec. To właśnie on po ośmiu latach został następcą Augustyna w Canterbury.

Zanim Augustyn zmarł w opinii świętości (27 V 604 lub 605 r.), konsekrował biskupów: Mellita i Justa. Mellit miał nauczać w East Saxons, prowincji ze stolicą w Londynie, oddzielonej od Kentu rzeką Tamizą. To właśnie w Londynie król Etelbert wzniósł kościół pw. św. Pawła jako siedzibę pierwszego biskupa Londynu Mellita i jego następców. Just został biskupem Heofescaestir (obecnie: Rochester), gdzie zbudował kościół pw. św. Andrzeja. Natomiast swoim bezpośrednim sukcesorem Augustyn uczynił Laurencjusza, przekonany, że bez biskupiej władzy Kościół w Brytanii może ulec zachwianiu. Laurencjusz zamierzał ów Kościół zjednoczyć, dlatego w napisanym przez siebie - w swoim imieniu oraz w imieniu Mellita i Justa - liście do biskupów Irlandii nie tylko powołał się na biskupa Dagana, opata Kolumbana w Galii, ale i prosił o jedność w Kościele (Bede 109-110). Laurencjusz zdołał też nakłonić króla Eadbalda do przyjęcia wiary chrześcijańskiej.

Za czasów Mellita i Justa, wspierających w posłudze misjonarzy, zmieniła się sytuacja religijna w Brytanii. Następcy Etelberta i Saberta przywrócili kult pogański, zmuszając w 616 r. Mellita (mającego także nawracać iroszkockie duchowieństwo) do opuszczenia Brytanii (por. Puchalska-Dąbrowska, Beda Czcigodny $i$ bohaterowie „Historii kościelnej narodu angielskiego” w polskim piśmiennictwie religijnym XVI-XVIII wieku 106). Po Mellicie sukcesję objął Just. Beda Czcigodny nie omieszkał jeszcze dodać, że to właśnie modlitwy Mellita przyczyniły się w cudowny sposób do ugaszenia w 619 r. pożaru w stolicy regionu (por. Bede 114-115).

W tym samym czasie jeszcze inny misjonarz głosił Ewangelię angielskim plemionom - zamieszkującym teren na północ od rzeki Humber, mianowicie Northumbrię. Był nim Paulin, arcybiskup Yorku i Rochester, benedyktyn z Monte Celio, który w 601 r. przybył wraz z Mellitem, Justem i Rufinianem do Brytanii na polecenie Grzegorza I Wielkiego. Owi misjonarze przywieźli 
sprzęt liturgiczny, święte księgi, paliusz dla Augustyna i list zawierający papieską wizję organizacji Kościoła w Anglii. To właśnie Augustyn, zobligowany przez papieża, erygował obie metropolie: w Londynie i Yorku, którym zamierzano podporządkować dwanaście biskupstw.

Dużo miejsca w swojej kronice Beda Czcigodny poświęcił chrystianizacji jego rodzimej Nothumbrii. Przyjęcie chrześcijaństwa przez Nothumbrię stanowiło owoc aliansu panującego nad nią króla Anglii Edwina z władcami Kentu. Początkowo Edwinowi odmówiono ręki księżniczki Etelburgi, córki króla Etelberta, mianowicie ze względu na trwanie w pogaństwie. Edwin dowiedział się, że nie dopuszcza się oddania chrześcijanki mężowi, który jest poganinem, oraz nie zezwala się na to, by wiara i sakramenty zbezcześciło jej związanie się z królem będącym ignorantem w kwestii kultu prawdziwego Boga. Edwin uzyskał zgodę na ślub z chrześcijanką dopiero wtedy, gdy obiecał, że nie przeszkodzi chrześcijańskiemu życiu, zapewni Etelburdze (nad którą sprawował duchową pieczę Paulin, kapelan księżniczki, mianowany biskupem przez Justa) i jej otoczeniu wolność w wierze i nabożnych praktykach oraz przyjmie chrzest, lecz uczyni to wtedy, gdy wiara chrześcijańska okaże się ,świętsza i bardziej zadowalająca od rodzimej” (Bede 118). Po rocznych naukach Paulin ochrzcił Edwina. Warto też podkreślić, że papież Bonifacy III wysłał list do Edwina, zachęcając władcę do stania się chrześcijaninem, i do Etelburgi, polecając jej, by wpłynęła na pozyskanie zbawienia przez króla. Co zadziwiające, również pogańscy doradcy przyczynili się do przyjęcia przez Edwina wiary chrześcijańskiej. Najwyższy kapłan pogańskiej religii miał przyznać, że w obliczu prawd nowej wiary dawne wierzenia wydają się nie mieć mocy i istnieć bez żadnej wartości. Następnie ów kapłan sam podjął się zniszczenia ołtarzy i świątyń bożków w pobliżu Yorku (Bede 129).

Edwina ochrzcił Paulin w dniu 12 kwietnia 627 r. w Yorku, „w Świętym Dniu Wielkiej Nocy”, w kościele pw. św. Piotra, i za zgodą tego króla głosił przez sześć lat Ewangelię na terenach podległych Edwinowi. Według Bedy Czcigodnego nieprzerwanie przez trzydzieści sześć dni miał Paulin udzielać w prowincji Lindsey, od rana do nocy, chrztu w wodach rzeki Glen oraz nauczać w Adgefrin o dokonanym przez Jezusa Chrystusa zbawieniu. Nadto król Edwin przekonał Earpwalda, syna Redwalda a króla East Angles, do porzucenia pogaństwa i przyjęcia „wiary i sakramentów Chrystusa” (Bede 132), jednak po zamordowaniu Earpwalda przez poganina Ricberta prowincja, nad którą tenże panował, na trzy lata popadła w pogaństwo, mianowicie do momentu przejęcia władzy po Earpwaldzie przez jego brata i chrześcijanina Sigberta. Ponowne wprowadzanie chrześcijaństwa w tym regionie przez nowego króla wspierał biskup Feliks, który już wcześniej pragnął głosić Ewangelię wśród Anglów, z czego zwierzył się Honoriuszowi, arcybiskupowi Burgundii. Stolicą Feliksa na siedemnaście lat stało się Dunwich. 
Northumbrię i jej króla nawrócił zatem na chrześcijaństwo Paulin, za co otrzymał paliusz od następcy Bonifacego III - papieża Honoriusza I. Honoriusz I skierował też do Edwina listy, w których z „ojcowską miłością rozpalającą gorliwość" zachęcał, by on i jego poddani trwali w otrzymanej wierze (Bede 135). Z grona misjonarzy należy jeszcze, ale już na marginesie, wymienić Wilfryda, który podjął się misji nawrócenia na chrześcijaństwo królestwa Sussex, a także działającego w pierwszej połowie VII stulecia, dobrowolnie wędrującego, irlandzkiego mnicha-wizjonera Furseusza, założyciela klasztorów i w Galii, i, co istotne dla tematu, w Anglii (Bede 22).

Beda Czcigodny, pisząc swoją kronikę, wychodził z założenia, że kondycja mieszkańców Ziemi nierozerwalnie wiąże się z ich relacją z Bogiem (por. Puchalska-Dąbrowska, Beda Czcigodny i bohaterowie „Historii kościelnej narodu angielskiego" w polskim piśmiennictwie religijnym XVI-XVIII wieku 64), w tym naturalnie kondycja mieszkańców Brytanii. Zaliczany do grona „narratorów historii krajów barbarzyńskich" (Thacker 172), podkreślał w swej kronice, mianowicie w kwestii chrystianizacji, rolę papiestwa jako czynnika sprawczego zmian dokonujących się na Wyspie i dzieł misjonarzy, nie omieszkując też wspomnieć o misyjnej działalności rodzimego duchowieństwa. Szczególną rolę w nawracaniu ludów anglosaskich przypisał Augustynowi z Canterbury, widząc w nim pierwszego na Wyspie misjonarza, który ,ją ochrzcił”.

Mimo iż kronika Bedy Czcigodnego jest owocem jego iście benedyktyńskiej (zresztą warto przypomnieć, że był benedyktynem) pracy, to i tak, jak założył sam autor, może zawierać nieścisłości. Prezentując historię Kościoła w Brytanii, przeplatającą się z dziejami świeckimi, Beda Czcigodny dopełniał niekiedy fakty historyczne legendarnymi opowieściami, np. o dokonywanych cudach. Napisał:

Szczerze pracowałem, aby podać dalej to, co tylko mogłem ustalić z powszechnego przekazu jako wskazówki dla przyszłych pokoleń. Gorąco proszę wszystkich, którzy usłyszą lub przeczytają tę historię naszego narodu, aby kierując się miłosierdziem, wybaczyli wiele niedociągnięć ducha i ciała. Wracając do rzetelnego trudu, jaki włożyłem w zapisanie pamiętnych wydarzeń w rozmaitych prowincjach i ważniejszych miejscach, bardzo proszę ich mieszkańców, by zechcieli zaszczycić mnie częstym wspomnieniem w gorliwej modlitwie (Bede 43).

Na temat owej kroniki Peter Hunt Blair twierdził, iż żadne inne dzieło nie jest w stanie równać się z nią popularnością. Warto teraz przypomnieć jeszcze kilka istotnych faktów z dalszych losów kroniki. Dzieło to przełożono w drugiej połowie IX w. - z inicjatywy króla Alfreda Wielkiego - na język anglosaski. Wiadomo też, że do współczesności zachowało się 150 średniowiecznych rękopisów kroniki, z których najdawniejsze powstały po upływie paru lat od 
śmierci Bedy Czcigodnego. Manuskrypty sporządzano jeszcze w XV stuleciu. W tymże wieku, a ukonkretniając: w 1475 r., pojawiła się w Strasburgu pierwsza wersja drukowana kroniki. Natomiast edycję, którą przetłumaczył na nowożytny język angielski Thomas Stapleton, zadedykowano królowej Elżbiecie I. Edycja ta ujrzała światło dzienne w 1565 r. w Antwerpii.

\title{
Zakończenie
}

Historia ecclestiastica gentis angelorum Bedy Czcigodnego to angielskie arcydzieło wczesnośredniowiecznej historiografii. Jako jedno z niewielu zachowanych do współczesności, skrupulatnie dokumentuje dzieje heptarchii. Wyłącznie na tych zapisanych w kronice świętego benedyktyna dziejach bazuje niniejszy artykuł. Beda Czcigodny koncentruje się w niej wokół historii Kościoła na Wyspie, ale wplata w ową historię również epizody ze świeckich dziejów, niemniej jednak pozostających w korelacji z dziejami kościelnymi. $\mathrm{Na}$ tle tej historii kreśli szczegółowo wizerunki świętych misjonarzy, którzy wprowadzali chrześcijaństwo na Wyspę. Jednakże nie zaczyna swej kroniki od zarania chrześcijaństwa na Wyspie, ale spogląda jeszcze dalej w przeszłość, ku postaci Juliusza Cezara. Swoje dzieło, sięgające w zapiskach VIII stulecia, w którego pierwszej połowie Beda Czcigodny zakończył swe ziemskie życie, kronikarz ten wieńczy, jak przystało na benedyktyna, błagalną, o obecność w niebie, modlitwą.

\author{
CHRISTIANISATION OF ENGLAND \\ ACCORDING TO THE ECCLESIASTICAL HISTORY \\ OF THE ENGLISH PEOPLE BY BEDE VENERABLE
}

\section{Summary}

Bede Venerable from Northumbria belongs to the group of the most prolific writers of the early medieval period. This Benedictine friar from Britain became famous thanks to his chronicle: Historia ecclesiastica gentis Angelorum, dedicated to the history of his motherland since the moment of Gaius Julius Caesar's arrival until the year 731. Thanks to this chronicle, but also his other historical records concerning, e.g. Benedictine abbots, Bede Venerable owes his name of 'the father of English historiography'. The issue of the Christianisation of Britain, connected with the continuous sending of missionaries on the British territory, creates the main part of this chronicle. This article is an attempt, undertaken with a certain amount of timidity, to outline the 
history of the introduction and renewal of Christianity in Britain based only on the chronicle written by Bede Venerable.

Keywords: Bede Venerable; Christianisation; Britons; Church; missions

Słowa kluczowe: Beda Czcigodny; chrystianizacja; Brytowie; Kościół; misje

\section{BIBLIOGRAFIA}

Bede. Ecclestiastical History of the English People. London: Penguin Random House, 1995 [thum. własne].

Bober, Andrzej. Anglia, Szkocja, Irlandia. Teksty źródtowe do historii Kościoła i patrystyki I-IX w. Lublin: TN KUL, 1991.

Cyrek, Olga. „Aktywność pastoralna i misyjna wczesnośredniowiecznych mnichów i pierwszych organizatorów życia monastycznego od IV do VII w.” Studia Paradyskie (2012) 22: 7-25.

Delap, Dana. Celtic Saints. Norwich: Pitkin Guides, 2003.

Karas, Marcin. „Kosmologia Bedy Czcigodnego (VIII wiek).” Roczniki Filozoficzne (2012) 60: 7-26.

Leciejewicz, Lech. Nowa postać świata. Narodziny średniowiecznej cywilizacji europejskiej. Wrocław: Wydawnictwo UWr, 2007.

Marecki, Józef. Rotter, Lucyna. Jak czytać wizerunki świętych. Leksykon atrybutów i symboli hagiograficznych. Kraków: Universitas, 2009.

Puchalska-Dąbrowska Bernadetta. „Beda Czcigodny i bohaterowie Historii kościelnej narodu angielskiego w Żywotach świętych Piotra Skargi." Vox Patrum (2016) 65: 565-584.

Puchalska-Dąbrowska Bernadetta. „Postać Bedy Czcigodnego w polskim piśmiennictwie religijnym XVI-XVIII wieku.” Tematy i Konteksty (2014) 9: 329-342.

Puchalska-Dąbrowska Bernadetta. Beda Czcigodny i bohaterowie „Historii kościelnej narodu angielskiego" w polskim piśmiennictwie religijnym XVI-XVIII wieku. Warszawa: Wydawnictwo Naukowe Sub Lupa, 2017.

Snyder, A. Christopher. Brytowie. Tłum. Katarzyna Bażyńska-Chojnacka i Piotr Chojnacki. Warszawa: Wydawnictwo UW, 2015.

Sprutta, Justyna. Kołodziejczyk, Dorota. „Beda Czcigodny - życie i twórczość. [Zarys historyczny]." Studia Gnesnensia (2019) XXXIII: 191-210.

Stenton, M. Frank. Anglo-Saxon England. Oxford: Oxford Clarendon Press, 2004 [tłum. własne].

The Cambridge Companion to Bede. Red. Scott DeGregorio. Cambridge: Cambridge University Press, 2010.

Zins, Henryk. Historia Anglii. Wrocław: Zakład Narodowy im. Ossolińskich, 2001.

Dorota KoŁodziEJCzyK, mgr pedagogiki w zakresie dydaktyki języków obcych. Nauczyciel języka angielskiego w Szkole Podstawowej nr 8 w Kaliszu. Podejmie studia doktoranckie na Wydziale Nauk Historycznych UKSW w Warszawie. 
